\title{
ACADEMISCHE EN NIET-ACADEMISCHE VORMING VAN DE ACCOUNTANT
}

\author{
door $M r$ B. Moret
}

Met bijzondere belangstelling heb ik kennis genomen van het artikel van Prof. Dr J. L. Mey over de academische en de niet-academische vorming van den accountant, dat verschenen is in het Aprilnummer van het Maandblad voor Accountancy en Bedrijfshuishoudkunde. Het daarin aangesneden probleem is ook naar mijn mening zeer actueel.

Hoewel ik mij met de strekking van dit artikel in grote lijnen geheel kan verenigen, komt bij mij toch de wens op enkele kanttekeningen hierbij te maken en deze ter kennis van de lezers van dit tijdschrift te brengen.

I. Ik zou dan willen opmerken, dat het aantal academisch gevormde accountants niet zo verrassend klein is als Prof. Mey meent. Volgens de door hem opgegeven cijfers bedragen de sinds 1938 afgestudeerde academisch gevormde accountants $30 \%$ van de niet-academisch gevormde. Dat dit aantal niet groter is, kan verklaard worden door een aantal bijzondere factoren.

In de eerste plaats werd in de betreffende periode de academische opleiding slechts op drie plaatsen in Nederland gegeven, te weten Amsterdam, Rotterdam en Tilburg. Door het feit dat de oorlog in die periode viel, met de maatregelen tegen studenten en de sluiting van de instellingen van hoger onderwijs, is het aantal academisch gevormde accountants klein gebleven. Het grote aantal studenten, dat na de oorlog met de studie is begonnen, heeft, door de lengte van de accountantsstudie van minstens 7 jaar, in het algemeen nog weinig afgestudeerden opgeleverd. Voorts dient bedacht te worden, dat tot nu toe in de kring van de beoefenaars van vrije beroepen met academische opleiding nog slechts bij uitzondering de wens gevoeld werd hun kinderen voor het accountantsberoep te doen opleiden. In het algemeen komen accountantsstudenten voort uit gezinnen, waar de vader niet academisch gevormd is en voor wie dus de voordelen van een academische opleiding niet sterk spreken en de kosten vaak een absolutut beletsel zijn.

Voor de toekomst verwacht $\mathrm{ik}$, speciaal indien de voorgestelde maatregelen ten aanzien van de kosten van het hoger onderwijs doorgang vinden, een belangrijke toename van het aantal academisch gevormde accountants in absolute en relatieve zin.

II. Prof. Dr J. L. Mey acht voor accountants een opleiding en vorming op academisch niveau noodzakelijk en wel om een drietal redenen:

1. Voor het verkrijgen van de benodigde economische en vooral bedrijfs economische scholing;

2. Voor de volledige geestelijke uitgroei en de verkrijging van een zeer grote mate van ,,common sense";

3. Voor het verkrijgen van het gewenste maatschappelijke aanzien.

Wat het eerste punt betreft, geloof ik, dat alle vakgenoten het met Prof. Mey eens zijn, dat de academische opleiding meer aandacht aan de economie en bedrijfseconomie besteedt dan de niet-academische, ook al houdt men rekening met de belangrijke verbeteringen door het Bureau der Examens van het N.I.v.A. in deze opleiding aangebracht.

Ten aanzien van het tweede punt ben ik niet zo zeker als Prof. Mey. De moeilijke financiële omstandigheden, waaronder veel studenten stu- 
deren, maakt, dat weinig mogelijkheid bestaat voor hen om te profiteren van de vormende kracht van de omgang met andere studenten en van de faciliteiten, die een Universiteit of Hogeschool biedt voor studie buiten het eigenlijke vakgebied. Daartegenover staat, dat de accountantsassistent, die na jarenlange avondstudie het N.I.v.A.-diploma heeft verkregen, daardoor bewezen heeft iemand te zijn van grote energie en volharding. De selectie, die door deze moeizame studie uitgeoefend wordt op de afgestudeerde accountants, acht ik veel groter dan bij de academische opleiding.

Het derde punt, door Prof. Mey naar voren gebracht, acht ik van groot belang.

Wanneer de accountant op voet van gelijkheid moet kunnen spreken met de leidinggevende figuren in de bedrijven, dan zal hij op die plaatsen in vele gevallen aantreffen ingenieurs, juristen of economen met een academische opleiding. Het is nu ontegenzeggelijk, dat een academische opleiding een sterke band vormt tussen allen, die een dergelijke opleiding genoten hebben, ook al heeft men aan verschillende inrichtingen van hoger onderwijs gestudeerd; een zekere "clan"-vorming is onmiskenbaar. Een niet-academisch gevormde accountant zal in deze kring altijd enigszins als een outsider worden beschouwd.

Ditzelfde probleem doet $z$ ich voor met den chef van de administratie van grote ondernemingen. In de meeste gevallen is deze chef van de administratie, ook in de allergrootste ondernemingen, opgekomen uit de kringen van het niet-academisch gevormde kantoorpersoneel; door de wel academisch gevormde bedrijfsleiders, directiesecretarissen, enz. wordt hij dan niet als een geheel gelijkwaardige partner geaccepteerd.

Bij het streven om, naar Amerikaans voorbeeld, de administratieve topfiguur in de onderneming een hogere plaats in de algehele bedrijfsleiding te geven, dient dit probleem ook onder de ogen te worden gezien. In het Nederlands Instituut voor Efficiency is dit vraagstuk reeds enige malen besproken; de Nederlandsche Economische Hoogeschool te Rotterdam heeft hieraan gedacht, toen enige tijd geleden de z.g. baccalaureaatsopleiding ter hand werd genomen, waarbij men door een kleine uitbreiding na het candidaatsexamen afgestudeerden wil afleveren, die niet te laat in het bedrijfsleven komen om daar nog een volledige leertijd door te maken. In hoeverre deze opleiding succes zal hebben, dient nog te worden af gewacht.

III. Het is goed, dat Prof. Mey in zijn artikel nog eens uitdrukkelijk wijst op de hoge eisen, die aan de opleiding van den accountant moeten worden gesteld. Men dient echter te bedenken, dat niet iedere accountant de leider van een groot kantoor zal worden of geroepen zal zijn zich in een andere functie te bewegen op het hoogste niveau van het bedrijfsleven. In de practijk is het nu eenmaal zo, dat veel afgestudeerde accountants in dienstverband werkzaam blijven, hetzij als medewerker van een public accountant, hetzij bij een grote onderneming of een overheidsdienst. De vraag naar accountants is nog steeds groter dan het aanbod en men kan de opleidingsmogelijkheid van het accountantsberoep langs de weg van de N.I.v.A.-examens op dit ogenblik zeker niet missen. In de practiik heeft deze opleiding uitstekende resultaten opgeleverd, al zijn er wellicht enkele nadelen aan verbonden in vergelijking met de academische opleidinq.

En tenslotte dient bedacht te worden, dat voor niemand de opleiding 
eindigt bij het behalen van het einddiploma. Zoals de academisch gevormde accountant op het moment van het behalen van het einddiploma een tekort kan hebben aan practische ervaring, zo kan de N.I.v.A.-accountant een tekort hebben aan theoretische beheersing van het terrein van de bedrijfseconomie of aan geestelijke uitgroei. En beide groepen zullen bij hun verdere beroepsuitoefening er naar moeten streven deze tekorten aan te vullen.

"EDERLAMDS INSTITUL"

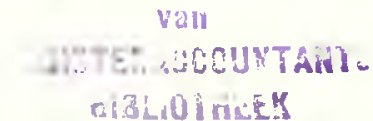

m a b blz. 390 